www.jmscr.igmpublication.org

Impact Factor 5.84

Index Copernicus Value: 71.58

ISSN (e)-2347-176x ISSN (p) 2455-0450

crossref DOI:_https://dx.doi.org/10.18535/jmscr/v5i9.77

Journal Of Medical Science And Clinical Research

IGM Publication

An official Publication of IGM Publication

\title{
A Comparative Study of Maximum Anal Dilatation with Fissurectomy and Lateral Anal Sphincterotomy in the Treatment of Fissure in Ano
}

\author{
Authors
}

\author{
Dr S. Ajay Venkatesh ${ }^{1}$, Dr R. Manoj Chandran ${ }^{2}$, Dr J.X.A. Manfred Fernando ${ }^{3}$ \\ ${ }^{1}$ Assistant Professor of Surgery, Dept of Surgery, Vinayaka Missions Kirupananda Variyar Medical College, \\ Vinayaka mission University, Salem, Tamil Nadu \\ ${ }^{2,3}$ Post Graduate Student, Dept of Surgery, Vinayaka Missions Kirupananda Variyar Medical College, \\ Vinayaka mission University, Salem, Tamil Nadu
}

\begin{abstract}
Aim: To Prospectively assess and evaluate the results of maximum anal dilatation with fissurectomy $v / s$ lateral anal sphincterotomy among the patients with fissure in ano.

Materials and Methods: A prospective comparative study was conducted at Vinayaka Missions Kirupananda Variyar Medical college and Hospital, Salem during the period between June 2013 -June 2015. 50 patients of fissure in ano were included in the study. After getting the written informed consent from the patients 25 patients were treated with maximum anal dilatation with fissurectomy and the other 25 patients had undergone the lateral anal sphincterotomy procedure for the fissure in ano.

Results: All the operated patients were followed up for a period of 3 months and the findings seen at the end of 3 months of follow up were bleeding was not present in both the maximum anal dilatation (MAD) with fissurectomy and lateral anal sphincterotomy group whereas all other features like pain, persistent spasm, fecal incontinence and delayed wound healing were present in almost 50\% patients in the maximum anal dilatation with fissurectomy group and none of the patients had any of these features in lateral sphincterotomy group and the difference was found to be statistically significant. $(p<.0001)$.

Conclusion: In the surgical treatment of chronic anal fissure not responding to conservative management, lateral internal sphincterotomy may be the better Treatment and perhaps the preferable surgical technique with fewer total complications when compared with maximum anal dilatation with Fissurectomy.
\end{abstract}

\section{Introduction}

Anal fissure is a common condition in young adults with an approximately equal sex ratio., The treatment of anal fissure whether surgical or medical, aims to reduce internal anal sphincter tone alone. ${ }^{3,4}$ Three dimensional ultrasonographic anatomy displays that the male anal canal, internal anal sphincter and external anal sphincter were longer than the female's respectively. ${ }^{5,6}$ Pressure studies conclude that maximal anal canal squeeze pressure is found where the pubo rectalis overlaps the external anal sphincter. This segment represents a significant proportion of anal canal length in women. The etiology is unclear, the main pathology appears to be a high resting anal pressure caused by increased internal anal sphincter tone. The chronic type of anal fissure lasts for $>8$ weeks. ${ }^{3,7}$ Pain is the most common presentation and may be associated with anal heat sensation. Conservative treatment which consists 


\section{JMSCR Vol||05||Issue||09||Page 27810-27817||September}

of warm sitz bath, dietary bran and topical analgesic and steroids have healing rates of approximately $80 \%$ within 3 weeks, but are not proven to be helpful for healing chronic anal fissure. ${ }^{4}$

The treatment of chronic anal fissure has changed greatly during the past two decades with ongoing research on medical approaches directed at lowering internal anal sphincter tone and avoiding the risk of fecal continence disturbance. Lateral internal sphincterotomy allows prompt healing in more than $90 \%$ of the patients with a low recurrence risk of $3 \%$ and hence it is being considered today the treatment of choice for fissure in ano. It offers predictable success rates and significantly lesser risk of permanent incontinence.

\section{Objectives}

To study and evaluate prospectively the outcome of treatment modalities such as maximum anal dilatation with fissurectomy and lateral anal sphincterotomy among the patients with fissure in ano.

\section{Materials and Methods}

Study design - Prospective comparison study

Study area - Vinayaka Missions Kirupananda Variyar Medical college and Hospital, Salem.

Study Period - June 2013 - June 2015

Study Population -50 patients of fissure in ano Sampling - Non random - purposive sampling

Inclusion criteria - All adult patients more than 25 years of age who had chronic anal fissure.

Exclusion criteria - Inflammatory bowel disease and any other associated rectal pathology.

A total of 50 patients were included in this study. After getting the written informed consent from the patients 25 patients were treated with maximum anal dilatation with fissurectomy and the other 25 patients had undergone the lateral anal sphincterotomy procedure for the fissure in ano.

\section{Results:}

Chart 1: Age Wise Distribution of the Study Population

\begin{tabular}{|c|c|c|c|c|c|}
\hline \multirow{2}{*}{ Age Group } & \multicolumn{2}{|c|}{$\begin{array}{l}\text { Maximum Anal Dilatation with } \\
\text { Fissurectomy }\end{array}$} & \multicolumn{2}{|c|}{ Lateral Anal Sphincterotomy } & \multirow{2}{*}{$\begin{array}{l}\text { P value (by Chi- } \\
\text { square test) }\end{array}$} \\
\hline & Frequency & Percentage & Frequency & Percentage & \\
\hline $20-30$ & 3 & $12 \%$ & 2 & $8 \%$ & \multirow{5}{*}{0.763} \\
\hline $31-40$ & 6 & $24 \%$ & 6 & $24 \%$ & \\
\hline $41-50$ & 10 & $40 \%$ & 9 & $36 \%$ & \\
\hline $51-60$ & 6 & $24 \%$ & 8 & $32 \%$ & \\
\hline Mean (SD) & \multicolumn{2}{|c|}{$43.8(8.34)$} & \multicolumn{2}{|c|}{$44.3(8.69)$} & \\
\hline
\end{tabular}

Chart 1 shows the age wise distribution of the study population. It is seen from the chart that the majority of the patients in both maximal dilatation with fissurectomy group and the lateral anal sphincterotomy group were in the age group of 30 - 50 years and the mean age in both the groups were almost similar.

Chart 1A: Age Wise Distribution of the Study Population

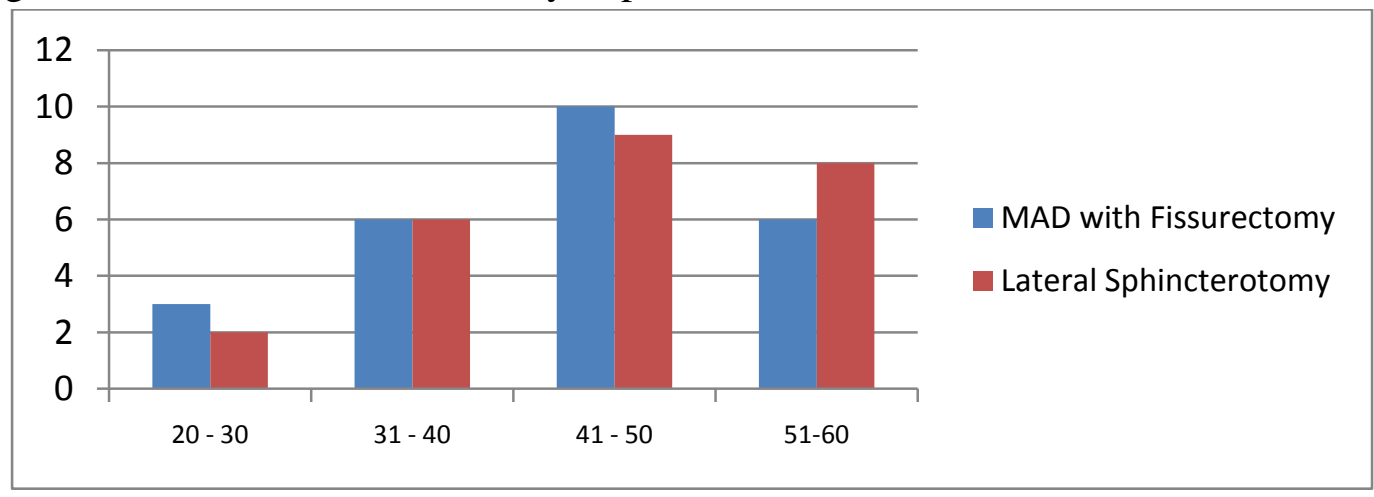




\section{JMSCR Vol||05||Issue||09||Page 27810-27817||September}

Chart 2: Gender Wise Distribution of the Study Population

\begin{tabular}{|l|c|c|c|c|c|}
\hline \multirow{2}{*}{ Gender } & \multicolumn{2}{|c|}{$\begin{array}{c}\text { Maximum Anal Dilatation with } \\
\text { Fissurectomy }\end{array}$} & \multicolumn{2}{c|}{$\begin{array}{c}\text { Lateral Anal } \\
\text { Sphincterotomy }\end{array}$} & \multirow{2}{*}{$\begin{array}{c}\text { P value (by Chi-square } \\
\text { test) }\end{array}$} \\
\cline { 2 - 5 } & Frequency & Percentage & Frequency & Percentage & \multirow{2}{*}{0.816} \\
\hline Male & 16 & $64 \%$ & 14 & $56 \%$ & $44 \%$ \\
\hline Female & 9 & $36 \%$ & 11 & $44 \%$ & \\
\hline Total & \multicolumn{2}{|c|}{25} & \multicolumn{2}{|c|}{25} & \\
\hline
\end{tabular}

Chart 2 shows the gender wise distribution of the study population. It is seen from the chart that both males and females were almost in equal proportions among the two groups and the male:

Chart 2A: Gender Wise Distribution of the Study Population

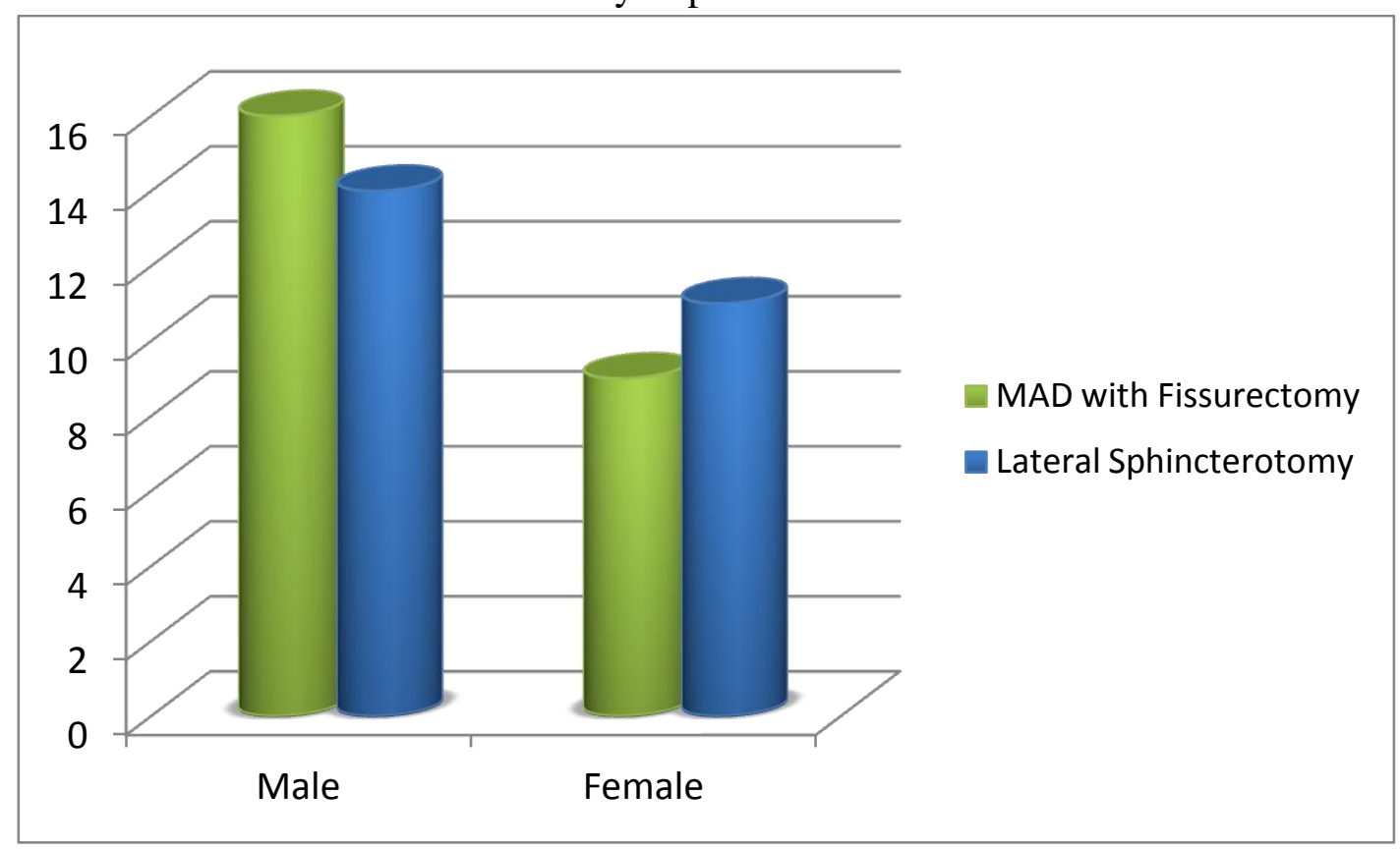

Chart 3: Occupation Wise Distribution of the Study Population

\begin{tabular}{|l|c|c|c|c|c|}
\hline \multirow{2}{*}{ Occupation } & \multicolumn{2}{|c|}{$\begin{array}{c}\text { Maximum Anal Dilatation with } \\
\text { Fissurectomy }\end{array}$} & \multicolumn{2}{c|}{ Lateral Anal Sphincterotomy } & $\begin{array}{c}\text { P value (by Chi-square } \\
\text { test) }\end{array}$ \\
\cline { 2 - 5 } & Frequency & Percentage & Frequency & Percentage & \\
\hline Manual Labor & 9 & $36 \%$ & 9 & $36 \%$ \\
\hline Driver & 3 & $12 \%$ & 2 & $8 \%$ \\
\hline House wife & 4 & $16 \%$ & 4 & $16 \%$ \\
\hline Tailor & 2 & $8 \%$ & 3 & $8 \%$ & \multirow{2}{*}{0.863} \\
\hline Fruit vendor & 3 & $12 \%$ & 2 & $20 \%$ & \\
\hline $\begin{array}{l}\text { Vegetable } \\
\text { Merchant }\end{array}$ & 25 & $16 \%$ & 5 & $100 \%$ & \\
\hline Total & $100 \%$ & 25 & $12 \%$ & \\
\hline
\end{tabular}

Chart 3 shows the occupation wise distribution of the study population. It is seen from the table that majority of the study population were manual female ratio among the maximum anal dilatation with fissurectomy group was 1.7: 1 and in the lateral anal sphincterotomy group it was $1.2: 1$. 


\section{JMSCR Vol||05||Issue||09||Page 27810-27817||September}

Chart 4: Distribution of the Study Population Based on their Duration of Pain

\begin{tabular}{|c|c|c|c|c|c|}
\hline \multirow{2}{*}{$\begin{array}{l}\text { Duration of } \\
\text { pain }\end{array}$} & \multicolumn{2}{|c|}{$\begin{array}{c}\text { Maximum Anal Dilatation with } \\
\text { Fissurectomy }\end{array}$} & \multicolumn{2}{|c|}{ Lateral Anal Sphincterotomy } & \multirow{2}{*}{$\begin{array}{l}\text { P value (by Chi- } \\
\text { square test) }\end{array}$} \\
\hline & Frequency & Percentage & Frequency & Percentage & \\
\hline 2 months & 5 & $20 \%$ & 7 & $28 \%$ & \multirow{5}{*}{0.658} \\
\hline 3 months & 9 & $36 \%$ & 12 & $48 \%$ & \\
\hline 4 months & 7 & $28 \%$ & 5 & $20 \%$ & \\
\hline 5 months & 4 & $16 \%$ & 1 & $4 \%$ & \\
\hline Mean & \multicolumn{2}{|c|}{$3.35(1.2)$} & \multicolumn{2}{|c|}{$3.5(1.3)$} & \\
\hline
\end{tabular}

Pain being the most commonest complaint among the patients with fissure in ano, chart 4 shows the distribution of the study population based on their symptom ranges from 2 months to 5 months and the mean duration of pain was almost similar in both the groups.

duration of pain. In both the study group the pain

Chart 4A: Distribution of the Study Population Based on their Duration of Pain

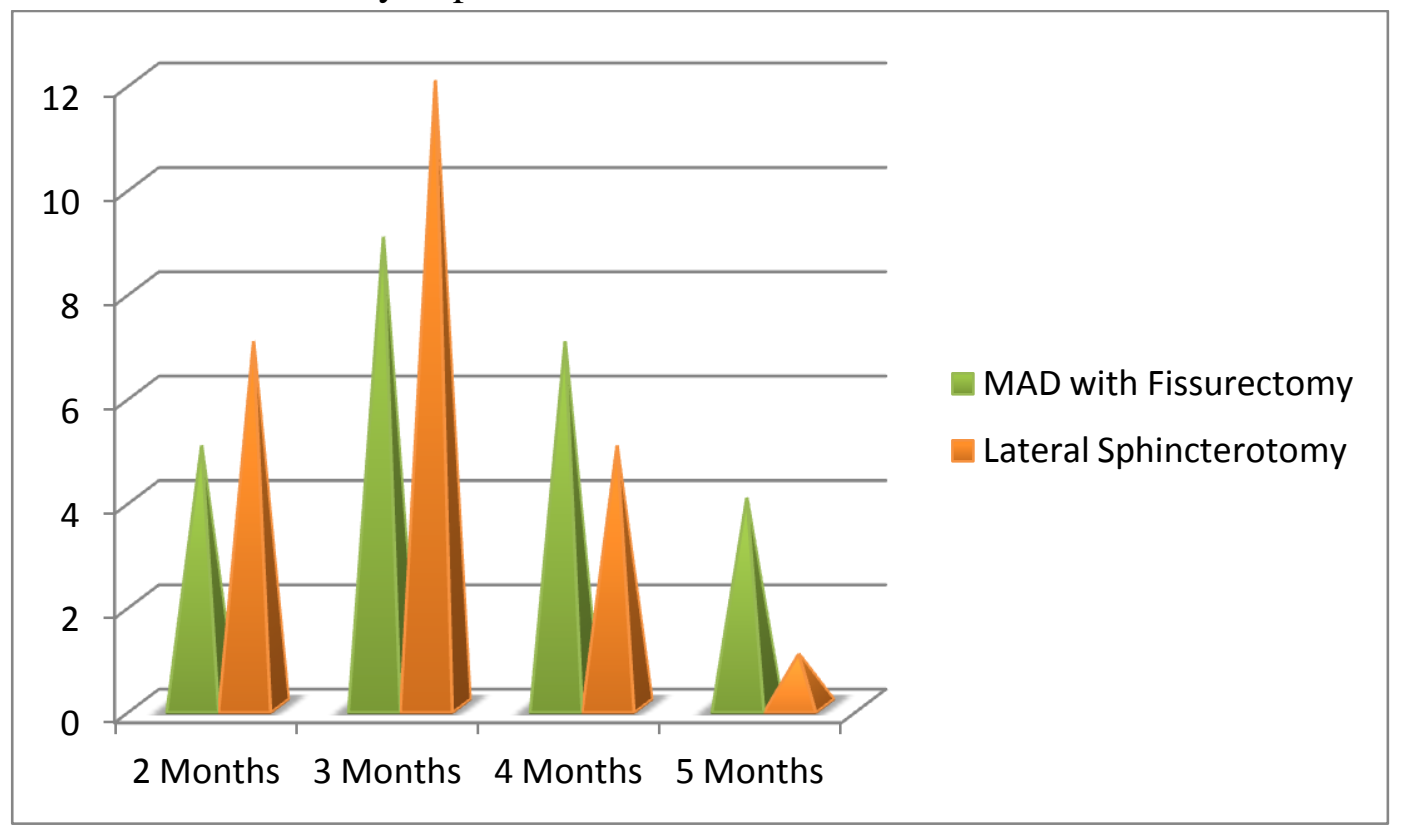

Chart 5: Distribution of the Study Population Based on their Duration of Bleeding Per Rectum.

\begin{tabular}{|c|c|c|c|c|c|}
\hline \multirow{2}{*}{$\begin{array}{l}\text { Duration of } \\
\text { pain }\end{array}$} & \multicolumn{2}{|c|}{$\begin{array}{l}\text { Maximum Anal Dilatation with } \\
\text { Fissurectomy }\end{array}$} & \multicolumn{2}{|c|}{ Lateral Anal Sphincterotomy } & \multirow{2}{*}{$\begin{array}{l}\mathrm{P} \text { value (by Chi- } \\
\text { square test) }\end{array}$} \\
\hline & Frequency & Percentage & Frequency & Percentage & \\
\hline 2 months & 5 & $20 \%$ & 7 & $28 \%$ & \multirow{5}{*}{0.658} \\
\hline 3 months & 9 & $36 \%$ & 12 & $48 \%$ & \\
\hline 4 months & 7 & $28 \%$ & 5 & $20 \%$ & \\
\hline 5 months & 4 & $16 \%$ & 1 & $4 \%$ & \\
\hline Mean & \multicolumn{2}{|c|}{$3.35(1.2)$} & \multicolumn{2}{|c|}{$3.5(1.3)$} & \\
\hline
\end{tabular}

Chart 5 shows the distribution of the study population based on their duration of bleeding per rectum. The duration of the symptom, bleeding per rectum was almost similar to that of the pain in both the groups. 


\section{JMSCR Vol||05||Issue||09||Page 27810-27817||September}

Chart 6: Distribution of the Study Population Based on their Duration of Constipation.

\begin{tabular}{|c|c|c|c|c|c|}
\hline \multirow{2}{*}{$\begin{array}{l}\text { Duration of } \\
\text { pain }\end{array}$} & \multicolumn{2}{|c|}{$\begin{array}{l}\text { Maximum Anal Dilatation with } \\
\text { Fissurectomy }\end{array}$} & \multicolumn{2}{|c|}{ Lateral Anal Sphincterotomy } & \multirow{2}{*}{$\begin{array}{l}\mathrm{P} \text { value (by Chi- } \\
\text { square test) }\end{array}$} \\
\hline & Frequency & Percentage & Frequency & Percentage & \\
\hline 2 months & 5 & $20 \%$ & 7 & $28 \%$ & \multirow{6}{*}{0.598} \\
\hline 3 months & 9 & $36 \%$ & 10 & $40 \%$ & \\
\hline 4 months & 6 & $24 \%$ & 5 & $20 \%$ & \\
\hline 5 months & 3 & $12 \%$ & 2 & $8 \%$ & \\
\hline Nil & 2 & $8 \%$ & 1 & $4 \%$ & \\
\hline Mean & \multicolumn{2}{|c|}{$3.05(1.2)$} & \multicolumn{2}{|c|}{$3.13(1.3)$} & \\
\hline
\end{tabular}

Chart 6 shows the distribution of the study population based on their duration of constipation.

Similar to the complaint of pain and bleeding PR, constipation is also one of the chief complaint of

fissure In ano and in our study population, among both the groups except 3 patients all the other patients all the other patient had the symptom of constipation.

Chart 7: Distribution of Study Population Based on their Findings of Rectal Examination

\begin{tabular}{|l|l|l|l|l|l|}
\hline \multirow{2}{*}{ Rectal examination findings } & \multicolumn{2}{|l|}{$\begin{array}{l}\text { Maximum Anal Dilatation } \\
\text { with Fissurectomy }\end{array}$} & \multicolumn{2}{l|}{$\begin{array}{l}\text { Lateral Anal } \\
\text { Sphincterotomy }\end{array}$} & $\begin{array}{l}\text { P value (by Chi- } \\
\text { square test) }\end{array}$ \\
\cline { 2 - 5 } & Frequency & Percentage & Frequency & Percentage & \\
\hline External Skin tag & 25 & $100 \%$ & 25 & $100 \%$ & 1.000 \\
\hline $\begin{array}{l}\text { Sphincter spasm (moderate } \\
\text { to severe) }\end{array}$ & 25 & $100 \%$ & 25 & $100 \%$ & 1.000 \\
\hline Tenderness & 25 & $100 \%$ & 25 & $100 \%$ & 1.000 \\
\hline Blood stained finger & 23 & $100 \%$ & 24 & $100 \%$ & 0.973 \\
\hline
\end{tabular}

Chart 7 shows the distribution of the study spasm, tenderness and the blood stained finger population based on their findings of rectal examination. The commonest findings in the rectal examination in both groups were presence of external skin tag, moderate to severe sphincter while conducting a PR examination, all these findings were almost present in all the study subjects.

Chart 7A: Distribution of Study Population Based on Their Findings of Rectal Examination

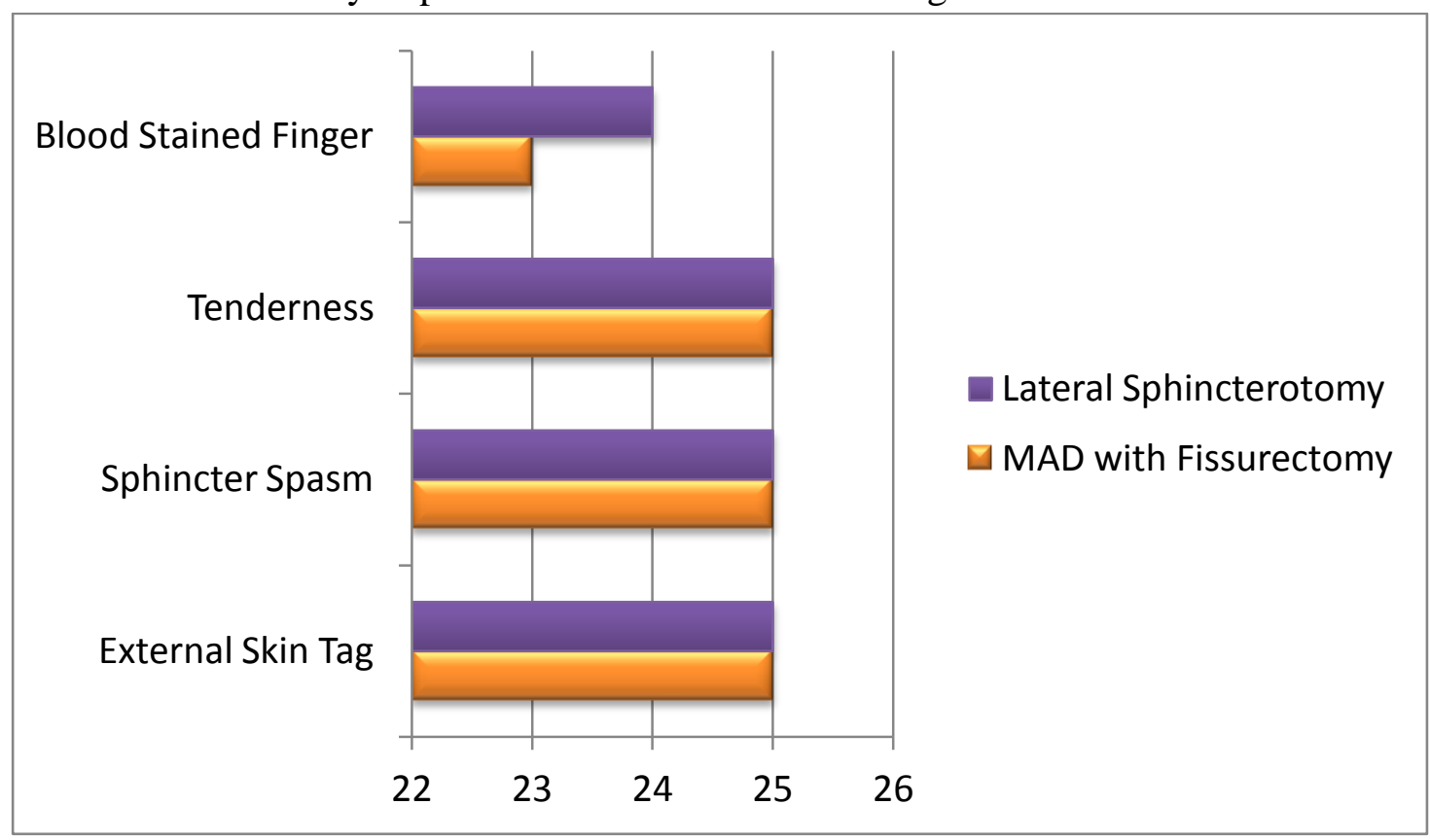




\section{JMSCR Vol||05||Issue||09||Page 27810-27817||September}

Chart 8: Distribution of the Study Population Based on the Type of Anesthesia Used for the Surgery

\begin{tabular}{|l|c|c|c|c|c|}
\hline \multirow{2}{*}{$\begin{array}{l}\text { Type } \\
\text { anesthesia }\end{array}$} & \multicolumn{2}{|c|}{$\begin{array}{c}\text { Maximum Anal Dilatation with } \\
\text { Fissurectomy }\end{array}$} & \multicolumn{2}{c|}{ Lateral Anal Sphincterotomy } & \multirow{2}{*}{$\begin{array}{c}\text { P value (by Chi- } \\
\text { square test) }\end{array}$} \\
\cline { 2 - 5 } & Frequency & Percentage & Frequency & Percentage & \\
\hline Spinal & 25 & $100 \%$ & 25 & $100 \%$ & 1.000 \\
\hline Total & 25 & $100 \%$ & 25 & $100 \%$ & \multirow{2}{*}{. } \\
\hline
\end{tabular}

Chart 8 shows the distribution of the study population based on the type of anesthesia used all the 50 patients were operated under spinal for the surgery. It is depicted from the table that anesthesia.

Chart 9: Presenting Features at the End of 3 Week Follow Up on the Patients of Both Types of Interventions

\begin{tabular}{|l|c|c|c|c|c|}
\hline \multirow{2}{*}{$\begin{array}{l}\text { Presenting } \\
\text { features }\end{array}$} & \multicolumn{2}{|c|}{$\begin{array}{c}\text { Maximum Anal Dilatation with } \\
\text { Fissurectomy }\end{array}$} & \multicolumn{2}{c|}{ Lateral Anal Sphincterotomy } & $\begin{array}{c}\text { P value (by Chi-square } \\
\text { test) }\end{array}$ \\
\cline { 2 - 6 } & Frequency & Percentage & Frequency & Percentage & $<.001$ \\
\hline Pain & 7 & $28 \%$ & 3 & $12 \%$ & $<.001$ \\
\hline Bleeding & 5 & $20 \%$ & 0 & 0 & $<.00001$ \\
\hline Spasm(persistent) & 16 & $64 \%$ & 3 & $12 \%$ & $<.0001$ \\
\hline $\begin{array}{l}\text { Faecal } \\
\text { incontinence }\end{array}$ & 14 & $56 \%$ & 7 & $28 \%$ & $<.0001$ \\
\hline $\begin{array}{l}\text { Wound healing } \\
\text { (not healed fully) }\end{array}$ & 16 & $64 \%$ & 0 & 0 \\
\hline
\end{tabular}

Chart 9 shows the presenting features at the end of 3 week follow up on the patients of both type of interventions. The following features were taken as the assessment parameters for comparison of the two procedures, they were pain, bleeding, persistent spasm, fecal incontinence and the wound healing. It is inferred from the chart that among the patients for whom lateral sphincterotomy was done had shown lesser number of patients with pain, fecal incontinence and delayed wound healing and there were also no patients with symptom of bleeding and intermittent spasm when compared with the patients who had undergone maximal anal dilatation with fissurectomy and this difference was found to be statistically significant $(\mathrm{p}<.0001)$

Chart 10: Presenting Features at the End of 3 Months Follow Up On the Patients of Both Types of Interventions

\begin{tabular}{|l|c|c|c|c|c|}
\hline \multirow{2}{*}{ Presenting features } & \multicolumn{2}{|c|}{$\begin{array}{c}\text { Maximum Anal Dilatation } \\
\text { with Fissurectomy }\end{array}$} & \multicolumn{2}{c|}{$\begin{array}{c}\text { Lateral Anal } \\
\text { Sphincterotomy }\end{array}$} & $\begin{array}{c}\text { P value (by Chi- } \\
\text { square test) }\end{array}$ \\
\cline { 2 - 5 } & Frequency & Percentage & Frequency & Percentage & \\
\hline Pain & 4 & $16 \%$ & 0 & 0 & $<.001$ \\
\hline Bleeding & 0 & 0 & 0 & 0 & 1.000 \\
\hline Spasm(persistent) & 10 & $40 \%$ & 0 & 0 & $<.00001$ \\
\hline Faecal incontinence & 12 & $48 \%$ & 0 & 0 & $<.0001$ \\
\hline Wound healing (not healed fully) & 13 & $52 \%$ & 0 & 0 & $<.0001$ \\
\hline
\end{tabular}

Chart 10 shows the presenting features at the end of 3 month follow up on the patients of both type of interventions. It is inferred from the chart that bleeding was not present in both the fissurectomy and lateral sphincterotomy group whereas all other features like pain, persistent spasm fecal incontinence and wound healing were present in almost $50 \%$ patients in the fissurectomy group and none of the patients had any of these features in the lateral sphincterotomy group and the difference was found to be statistically significant $(\mathrm{p}<.0001)$. 


\section{Discussion}

Anal fissure is a longitudinal defect of the anal canal mucosa and anoderm, extending usually from the dentate line to the external verge of the anal canal and was recognized as a clinical entity in $1934 .^{8}$ Acute fissures usually heal with conservative treatment. Fissures lasting longer than 2 months with features of chronicity such as sentinel skin tag, hypertrophied anal papillae and fibrous polyps, exposure of the underlying anal sphincter or anal cicatrisation are unlikely to heal with conservative management. ${ }^{9}$ Atypical fissures may be multiple, or be large and irregular. They usually are caused by inflammatory bowel disease, local or systemic malignancy, venereal infection, trauma, tuberculosis or chemotherapy and they are unlikely to be resolved with conservative management. ${ }^{10}$

The cause of anal fissure remains controversial although it has been recognized that anal fissures are probably caused by internal anal sphincter hypertonia, ${ }^{11-13}$ which produces ischemia of the posterior commisure of the anus. This explains the presence of sphincter spasm, ischemic severe pain, predilection for the posterior midline and poor healing. It also explains how surgery by disrupting the internal anal sphincter and improving anodermal blood flow allows the fissure to heal.

Surgery achieves high rates of anal fissures healing with a low recurrence rate. ${ }^{14}$ Maximum anal dilatation results in successful healing of anal fissures. However there is no way to reliably standardize the procedure and both the internal and external sphincters can be disrupted or fragmented in an irregular manner. ${ }^{15}$ As a result, sphincter damage occurs in $65 \%$ of patients undergoing maximum anal dilatation, with a significantly higher risk of minor incontinence than sphincterotomy. ${ }^{16}$

Anal dilatation also has a higher risk of fissure persistence compared with lateral internal sphincterotomy. ${ }^{17} \mathrm{~A}$ method combining the age-old technique of manual dilatation followed by radio surgery is found to be useful for refreshing the edges of the fissure and to tackle pathologies such as sentinel pile, small internal piles or hypertrophied anal papillae. ${ }^{18}$ Revisiting the trends of treatment of chronic anal fissures, the preferred options are manual dilatation with radio surgery and the subcutaneous lateral anal sphincterotomy. ${ }^{19}$

Calcium channel blocker act by blocking the slow L-type channels causing smooth muscle relaxation thereby decreasing resting anal pressure therefore helpful in anal fissures. Fissurectomy with posterior internal sphincterotomy is considered less effective than lateral anal sphincterotomy. It has largely been abandoned because of presumed longer period of wound healing and higher incidence of disturbed continence. ${ }^{20,21}$ Chronic fissure have traditionally been managed with lateral anal sphincterotomy. It promises rapid relief of pain and is simple to perform. It is treatment of choice in chronic anal fissure for many surgeons.

\section{Conclusion}

In the surgical treatment of chronic anal fissure not responding to conservative management, lateral anal sphincterotomy may be the better treatment and perhaps the preferable surgical technique with fewer total complications when compared with maximum anal dilatation with Fissurectomy. Small sample size and the objective measurements like assessment of pressure of the internal anal sphincter, which was not done in the present study are the major limitations of this study. So large multicentric studies had to be carried out with more number of patients and comparisons with continuous pressures and ultrasonographic measurements to substantiate the findings.

\section{References}

1. Steven.D.Wexener, Pruritus Ani and Anal Fissure (18). In:David.E.Beck and David. R.Welling editor. Patient care in colorectal surgery, $2^{\text {nd }}$ edition;1991. P243-254. 
2. Cook T.A, Brading A.F, Mortensen N.J. $\mathrm{McC}$. Contractile properties of ano rectal smooth muscle. Br J Surg 1999;86:70-75.

3. Stebbing J.F, Brading A.F.Mortensen N.J. Nitregenic inhibitory innervation of procrine rectal circular smooth muscle. $\mathrm{Br}$ J Surg 1995;85:1183-7.

4. Robert J.C. Steele and Kenneth Campbell. Disorders of anal canal(15). In:Sir Alfred Cuschieri, Robert J.C.Steele and Abdool Rahim Moosa editors. Essential Surgical practice, $4^{\text {th }}$ edition 2002. P642-643.

5. B.Williams, M.J.Cheetham, C.I Bartram, S.Hallinga n,M.A.Kamm.R.J.Nicholls and W.A.Kmiot. Gender differences in the longitudinal pressure profile of the anal canal related to anatomical structure sa demonstrated on three dimensional anal endo-sonography from: URL: http://www.bjs.co.uk/87/12/abstract/bjs19 58.asp.

6. M.M.Fynes, M.Behan, C.O'herlihy and P.R.O'connel. Anal vector volume analysis complements endo-anal ultrasonographic assessment of postpartal anal sphincter injury from URL: http:/ /www.bjs.co.uk/87/9/abstract/bjs1958.asp.

7. Terry C.Hicks and Frank G.Opleka. Rectal and perianal complaints(30). In:Hirman C.Polk, Jr. Bernand. Gardner and H. Harlon Stone editors. Basic Surgery, $4^{\text {th }}$ edition 1993.p.550-551.

8. Dziki A, Trzcinski R, Langner E, Wronski W. New approaches to the treatment of anal fissure. Acta Chir Iugosl 2002;49:73.

9. Gupta PJ. A study of hypertrophied anal papillae and fibrous polyps associated with chronic anal fissures. Rom J Gastroenterol 2004;13:103-107.

10. Nelson R. Treatment of anal fissure(Editorial). BMJ 2003;327:354-355.

11. Bove A, Balzano A, Perotti P, Antropoli C, Lombardi G, Pucciani F. Different anal pressure profiles in patients with anal fissure. Tech Coloproctol 2004;8:151-156.
12. Ammari FF, Bani-Hani KE. Faecal incontinence in patients with anal fissure: a consequence of internal sphincterotomy or a feature of the condition? Surgeon 2004;2:225-229.

13. Sandelewski A, Korenza J, Dyaczynski M, Tomsia D. Chronic anal fissure conservative or surgical treatment? Wiad Lek 2004;57:80-84.

14. Lindsey I, Jones OM, Cunningham C, Mortensen NJ. Chronic anal fissure. Br J Surg 204;91:270-279.

15. Nielsen MB, Rasmussen OO, Pedersen JF, Christiansen J. Risk of sphincter damage and anal incontinence after anal dilatation for fissure in ano. An endosonographic study. Dis colom Rectum 1993;36:677680.

16. Nelson R, Mehrabian E. Meta-analysis of operative techniques for fissure in ano. Dis Colon Rectum 1999;42:1424-1428.

17. Nelson R. Operative procedures for fissure in ano. Cochrane Database Syst Rev 2002;CD002199.

18. Gupta JP. Current trends of management for fissure in ano. Rom $\mathrm{J}$ Gastroenterol 2002;11:25-27.

19. Gupta JP. Sphincterotomy with radio frequency surgery: a new treatment technique of fissure in ano and associated pathologies. Rom J Gastroenterol 2003;12;37-40.

20. Sohn N, Eisenberg MM, Weinstein MA, Lugo RN, Ader J. Precise anorectal sphincter dilatation - its role in the therapy of ana fissure. Dis Colon Rectum 1992; 35:322-7.

21. Dicastro A, Biancari F, D'Andrea V, Caviglia A. Fissurectomy with posterior midline sphincterotomy and anoplasty in the management of chronic anal fissures. Surg Today 1997;27;975-8. 